\title{
Aviv barley and calendar diversity among Jews in eleventh-century Palestine
}

\author{
NA D I A V I D RO \\ UNIVERSITY C OLLEGE LONDON, UK
}

AвsтRACт One of the most salient medieval Qaraite practices was setting the calendar by observation of natural phenomena. While the Rabbanites followed arithmetical schemes, Qaraites set months by sighting the new moon and intercalated years on the basis of the state of ripeness of barley crops (aviv). Multiple Qaraite treatises on the aviv are preserved, but documentary evidence of empirical intercalation is scarce, making it difficult to learn how it was performed in practice. This article examines two Qaraite calendar chronicles that document barley observations and decisions regarding intercalation in a range of years in the eleventh century. They shed important light on how the Qaraite calendar operated over periods of time and attest to frequent calendar difference within the Qaraite movement and between Qaraites and Rabbanites. The chronicles make it clear that the Qaraite calendar of the period was not a monolithic system counterposed to that of the Rabbanites.

$\mathrm{O}$ NE OF THE MOST SALIENT PRACTICES that distinguished medieval Qaraite Jews from the mainstream Rabbanites was setting the calendar by the observation of natural phenomena. Unlike the Rabbanites, who followed a mathematical scheme for setting the calendar, Qaraites fixed beginnings of months by observing the new crescent and determined whether to intercalate the year on the basis of the state of barley crops. ${ }^{1}$

The Qaraite empirical intercalation was grounded in the biblical commandment to celebrate Passover in 'the month of aviv' (Deut. I6:I), which

This article was researched and written as part of the project 'Qaraite and Rabbanite Calendars: Origins, Interaction, and Polemic', funded by the Fritz Thyssen Foundation. I am grateful to Professor Sacha Stern (UCL) and Dr Ben Outhwaite (CUL) for commenting on an earlier version of the article. I thank Dr Amir Ashur (Tel Aviv University) and Professor Judith Olszowy-Schlanger (Oxford) for their help with assessing the manuscripts' handwriting.

I. Z. Ankori, Karaites in Byzantium: The Formative Years, 970-1100 (New York: Columbia University Press, I959), pp. 292-3; D.J. Lasker, 'Calendar and Calendar Disputes', in Encyclopedia of Jews in the Islamic World (accessed 3I March 2020); M. Rustow, Heresy and the Politics of Community: The Jews of the Fatimid Caliphate (New York: Cornell University Press, 2008), pp. 57-6I.

JOURNAL OF JEWISH STUDIES | VOL. LXXII NO. 2 | AUTUMN 202I | pp. 283-3I2 | ISSN 0022-2097| https://doi.org/I0.18647/3504/JJs-202I | https://orcid.org/oooo-0002-3668-IO0x | COPyright (C) Oxford Centre for Hebrew and Jewish Studies, 202I.

O Open access article under C C-B Y-N C-N D licence, freely available from the JJS website. 
is the month when crops reach a particular state called aviv. In the Bible the term aviv is specifically collocated with barley and described as a progressed stage in its growth, when it can be ruined by hail and parched with fire (Exod. 9:3I, Lev. 2:I4). The basic Qaraite intercalation procedure was simple: barley fields were examined twelve months after the beginning of the previous Nisan. If barley in the correct stage of ripening was found, that month was declared the first month of the year and Passover could be celebrated. If barley was not sufficiently ripe, the year was intercalated by adding an additional thirteenth month. This procedure involved many parameters that could not be established unambiguously on the basis of the biblical text. What exact stage in the ripening of barley should one look for? When and where should barley in the correct stage be found? How much barley should be present in order to celebrate Passover?

Multiple opinions on how to intercalate the year by observing barley crops are recorded in medieval Qaraite sources, such as books of commandments, Bible commentaries and polemical treatises on the calendar. ${ }^{2}$ This diversity is noted already by al-Qirqisānī in tenth-century Iraq:

One says about the aviv that it is the tender grain. Another does not begin the month of aviv till ripe grain is found in the entire Land of Israel. Yet another begins it when one plot of land is ready for harvest. Yet another will do that [declare the month of aviv] on a few handfuls of ears only. ${ }^{3}$

If used in practice, these different systems of intercalation would have produced incompatible results and must have led to groups within the Qaraite movement sometimes celebrating Passover and the rest of the festivals a month apart.

Few medieval Qaraite calendars and barley observation records have so far been identified. Oxford, Bodleian Heb. b. II.Io is a letter about the aviv sent from Jerusalem to a Qaraite leader in Fustat, probably in Io44. ${ }^{4}$

2. For example, al-Qirqisānī, Book of Lights and Watchtowers v i I.I6-2I (L. Nemoy, Kitāb al-Anwār wal-Marāqib [New York: Alexander Kohut Memorial Foundation, 1939-43], vol. 4, pp. 833-50); books of commandments by Israel b. Daniel, Yefet b. 'Eli, Sahl b. Mașliaḥ, Levi b. Yefet; Yūsuf alBașīr, Kitāb al-Istibșār, book 4; an anonymous intra-Qaraite polemic on the aviv; Bible commentaries by Yefet b. 'Eli, Yūsuf ibn Nūḥ, etc. The bulk of this literature is still unedited. Brief references to some books of commandments in the context of aviv are found in Ankori, Karaites in Byzantium, pp. 322-3; M. Gil, A History of Palestine, 634-1099 (in Hebrew; Tel Aviv: Tel Aviv University Press, I983), vol. I, secs. 928-9.

3. Al-Qirqisānī, Book of Lights and Watchtowers I.19.2 (Nemoy, Kitāb al-Anwār, vol. I, pp. 60-6I).

4. Gil, $A$ History of Palestine, vol. 2, pp. 540-43 (doc. 30I). 
T-S I2.I47 is a copy of an official document regarding the state of barley fields in Gaza in March Ios2 compiled by a delegation of twelve Qaraites. ${ }^{5}$ T-S I2.646v and T-S AS I57.74v, from a Qaraite book of court records, describe the state of crops on a number of fields, and are datable to the first half of the eleventh century. ${ }^{6}$ Meanwhile, ENA 40I0.35, ENA 4I96.I5, T-S K2.I07r and T-S NS J 6o9r preserve a Qaraite calendar roster for 1047/8 and IO49-5I CE. ${ }^{7}$ These are important witnesses of the Qaraite empirical calendar. However, they document either the state of fields (observation reports) or decisions about intercalation (the roster) and do not establish correspondences between observed states of crops and calendrical decisions. Moreover, most of the documents cover single years only. These documents are of limited use for learning how empirical intercalation was performed in practice and for studying calendar diversity.

Recently two manuscripts have come to light that document events related to intercalation as it was performed by Palestinian Qaraites in the nine years between IOI9 and IO28 CE. These manuscripts have three important features: they cover a range of consecutive years; they record information on inspecting barley fields together with decisions regarding intercalation made on the basis of the observed state of crops; and they refer to calendar decisions of different Qaraite groups. As such these calendar chronicles shed important light on how the Qaraite calendar operated over periods of time.

In this article I present an edition and English translation of the fragments, followed by an analysis of their contents and a discussion of intra-Qaraite and Qaraite-Rabbanite calendar diversity as it plays out in the chronicles. My analysis demonstrates that various incompatible opinions discussed in theoretical works on the aviv were followed in practice. This led to practical calendar diversity among Qaraites on a scale that makes it unjustified to regard the Qaraite calendar as a monolithic calendar counterposed to that of the Rabbanites.

5. Ibid., pp. 543-5 (doc. 302).

6. For T-S I2.646 see S.D. Goitein, A Mediterranean Society: The Jewish Communities of the Arab World as Portrayed in the Documents of the Cairo Geniza, vol. 4 (Berkeley CA: University of California Press, I967-93), p. 4I8 n. 363. T-S AS I57.74 is another fragment from the same original manuscript.

7. M. Gil, The Tustaris: The Family and the Sect (in Hebrew; Tel Aviv: Tel Aviv University Press, I98I), pp. 86-94. 


\section{Manuscripts}

Russian National Library (RNL) Evr Arab I II5I is a collation of information on the seeking of the aviv and decisions made on its basis in the years $4 \mathrm{I} 3-\mathrm{I} 8$ A H (April I022-February I028 CE). The fragment consists of two consecutive leaves, now separate, which must have originally constituted the central bifolio of a quire. It is copied in a late eleventh-twelfth-century Oriental handwriting. T-S AS I58.I47 is a very similar record for the years 4IO-I2 A H (May I0I9-April I022) and another unidentifiable year. The fragment consists of one leaf with a stub and is in a late-twelfth-thirteenth-century Oriental handwriting. Both manuscripts are in Judaeo-Arabic.

\section{Text and translation}

T-S AS 158.147, verso

ען j קפיזא אב. מנהא אכצר דג[?]

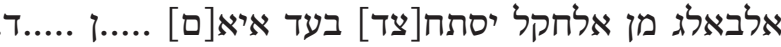

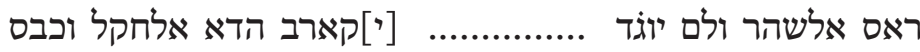

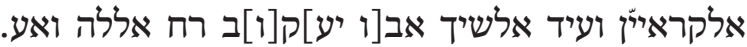

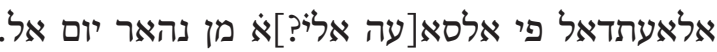

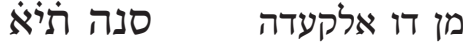

לם יוגד פי דו אלקעדה שי ועידת אלגמאעה בלא שך [פי]

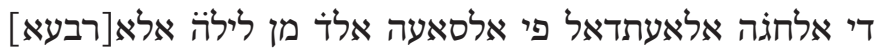
אלذט מן [די] אלקע[דה] תלת[א] אלתאסע ואליקשרין מ[ו] עליהא אלא... (1).

$T-S A S$ 158.147, recto

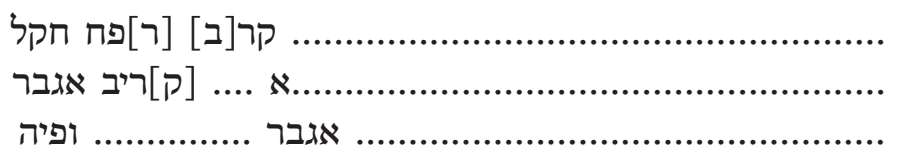

8. Square brackets represent conjectures due to lacunae and other damage to the manuscripts, such as rubbing. 


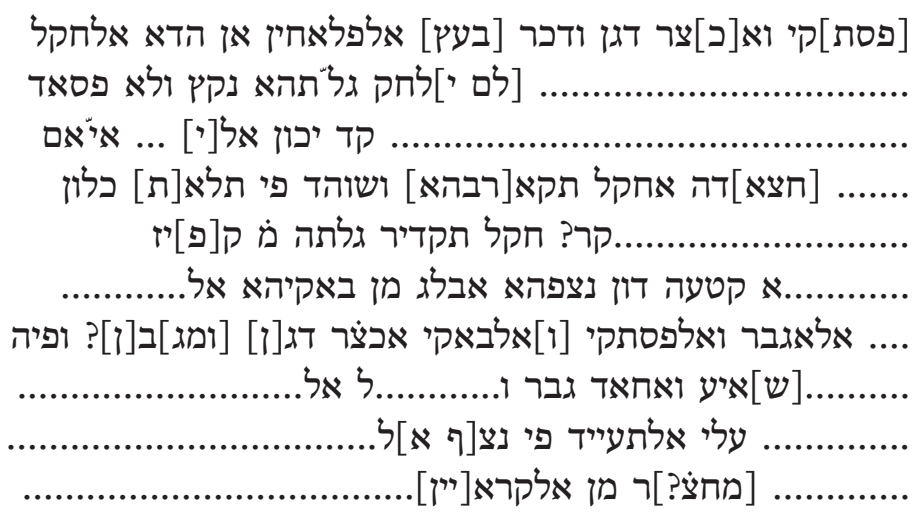

\section{T-S AS 158.147, verso}

about 50 qafi $z^{9}$

of them green and doughy ${ }^{10}$

the ripe [part] of the field will be harvested in .... days

beginning of the month and was not found .......... close [in terms of growth stage] to this field.

The Qaraites intercalated and the elder Abū Yáqūb, may God have mercy for him, celebrated and

The equinox is in the eleventh(?) hour of the day on the

of Dū al-Qa dah. Year 4 II

Nothing could be found in Dū al-Qa dah and the community celebrated, without any doubts, in

Du al-Hijjah. The equinox is in the fourth hour of the night of Wednesday,

the 29th of Dū al-Qa'dah.

Year 4I 2

Tuesday, the 29th of ..

on it

T-S AS 158.147, recto

near Rafah a field

almost dust-coloured

dust-coloured and in it

pistachio-coloured and green and doughy. Some peasants mentioned that this field

9. Qafiz is a measure of capacity typically used for grain and flour (W. Hinz, Islamische Masse und Gewichte: Umgerechnet ins metrische System (Leiden: Brill, I970), pp. 48-50).

Io. For barley growth stages, see 'Aviv barley and other barley growth stages' below. 
its crop is not affected by damage or decay can be in ... days

his harvesting of fields that are in a similar [growth stage]. When three nights have passed a field was inspected, the yield of which was estimated to be 40 qafiz a piece less than half of it that was riper than the rest of the [field] dust-coloured and pistachio-coloured and the rest was green and doughy and curdled ${ }^{11}$ and in it widespread and turned dust-coloured. And the about celebrating in the middle of the report(?) from the Qaraites

RNL Evr Arab I 1151

$$
\begin{aligned}
& \text { אל[אעתדא]לי פי אלסאעה אלה מן יום אלגמעה אל... } \\
& \text { [מן די אלחג]ה }
\end{aligned}
$$

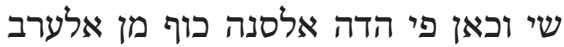

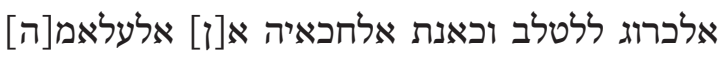

$$
\begin{aligned}
& \text { אלסנה פאמא אלמעלם [אבו סעי]] } \\
& \text { כ[ר]: אלי [ע][מל אלרמלה וגירהא }
\end{aligned}
$$

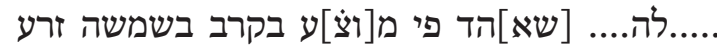

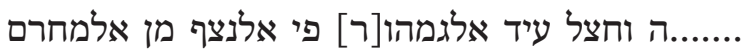

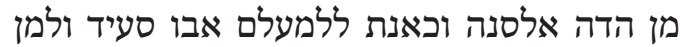

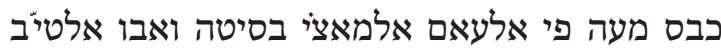

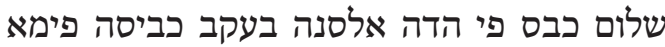

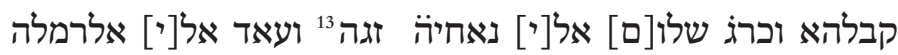

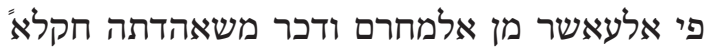

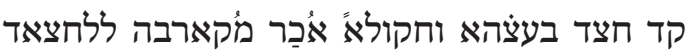

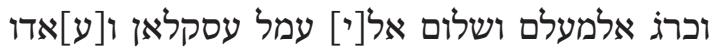

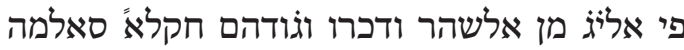

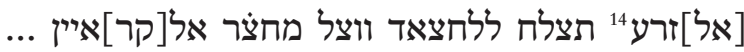

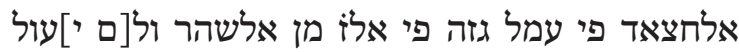

$$
\begin{aligned}
& \text { שלום עלי גמיע דאך אלאעתדאל פי פי אלב מל מל .. }
\end{aligned}
$$

II. On this term, see 'Aviv barley and other barley growth stages' below.

I2. Fol. Ir.

I3. See 'Locations where fields were inspected' below.

I4. Fol. Iv. 
סנה תיוּ לם יתמכן אצחאבנא [מן] אלכרוג פי הדה אלסנה לאגל כוף אלט[ר]יק ומין ו...

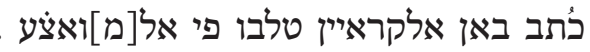

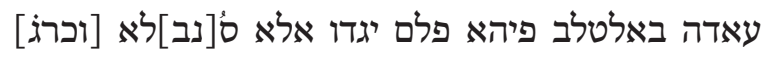

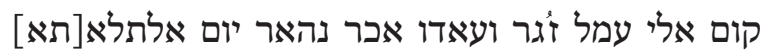

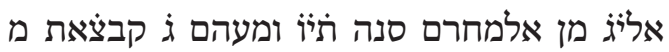

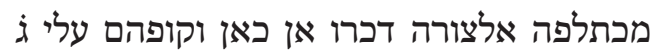

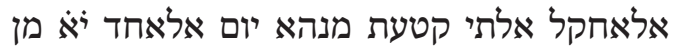

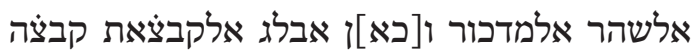

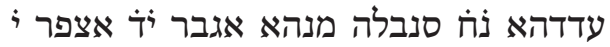

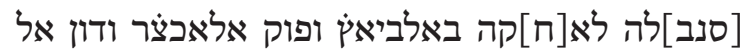

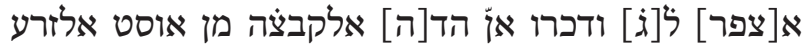

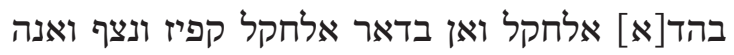

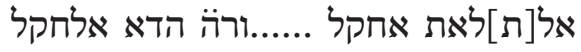

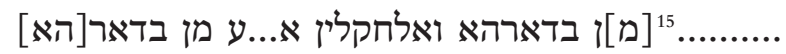

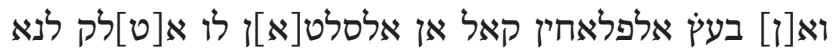

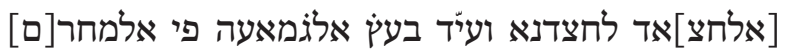

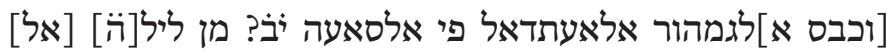

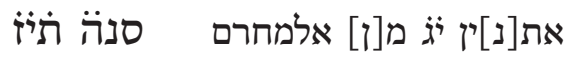

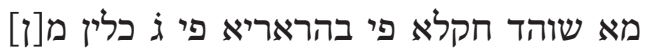

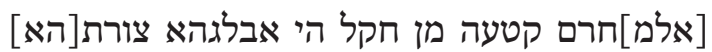

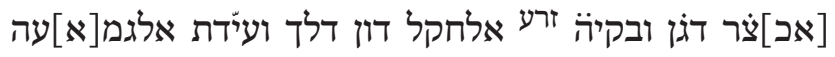

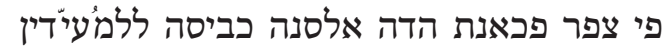

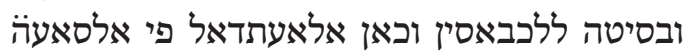

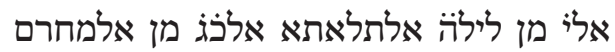
סנה תיח מילה

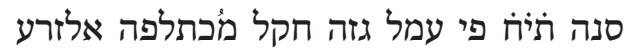

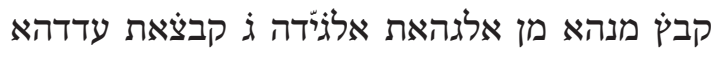

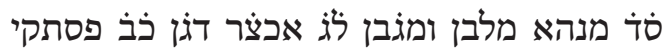

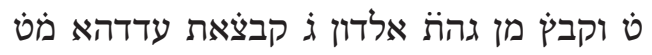
מנהא

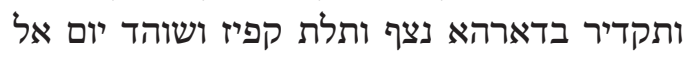
אתנין חקל קבץ מן אלגהה אלגידה ג קבצאת 


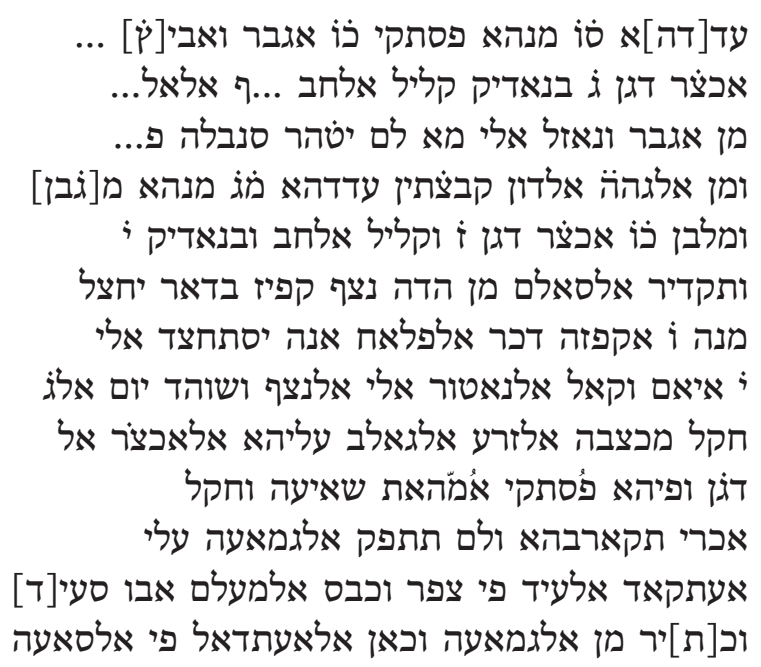

\section{RNL Evr Arab I 1151}

The equinox was in the 5 th hour in the daytime of Friday the ... of Dū al-Hijjah Year 4Is because in year 4I4 [we] did not anything. ${ }^{17}$ In this year there was a fear of the Bedouins ${ }^{18}$ going out to search. It was related that the sign was the year. As for the teacher Abū Saîd went out to the district of Ramla and to other places inspected grain in a place near בשמשה The majority celebrated the festival in the middle of Muharram of this year. For the teacher Abū Sa īd and for those who intercalated the previous year with him this year was plain. But Abū al-Tayyib Šalom intercalated this year after intercalating the one before it. Šalom went out to the area of ${ }^{20}$ and returned to Ramla on the Ioth of Muharram. He mentioned that he inspected a field some of which had already been harvested and other fields that were close to being harvested.

I7. This sentence probably said something like 'in year $4 \mathrm{I} 4$ we did not do anything'. This is because the decision to intercalate was made at the end of $4 \mathrm{I} 3 \mathrm{~A} \mathrm{H}$, and the intercalary month Adar II corresponded to Dū al-Hijjah of that year (see T A B LE 2 in the Appendix). The crops were next examined in the beginning of $4 \mathrm{I} 5 \mathrm{AH}$.

I8. The 'fear of the Bedouins' in 4I5 A H (March I024-March I025) and the 'fear of the road' in 4I6 A H (March I025-February I026) must have been caused by the Bedouin uprising in Palestine in ro24-29 C e (Gil, A History of Palestine, vol. I, secs. 580-93). Although the main military action took place between the summer of I024 C E and spring I025 C E, the situation could have been tense already in the spring of IO24 CE.

19. See 'Locations where fields were inspected' below.

20. See 'Locations where fields were inspected' below. 
The teacher and Šalom went out to the district of Ascalon and returned on the I3th of the month. They mentioned finding a healthy field, the grain on which was ready for harvesting. And there arrived a report from the Qaraites [about] the harvest in the district of Gaza on the 7th of the month but Šalom did not rely on all this. The equinox was in the second of

Year 4I6 Our members were unable to go out this year for fear of the road ${ }^{21}$

letters that the Qaraites sought in the places in [which it is]

habitual to seek. But they found nothing but [separate] ears. People went out to the district of Zoar and returned in the afternoon of Tuesday, the I3th of Muharram of the year 4I6. They brought three handfuls [of ears] in different growth stages. They mentioned that they inspected three fields, from which these were cut, on Sunday, the IIth of the mentioned month. The ripest of the handfuls was a handful counting 58 ears, of which 14 were dust-coloured, Io yellow, one ear was close to whiteness and 33 were above green but not yet yellow. They mentioned that this handful was from the middle of the grain on this field, and that one and a half qafiz of seeds [were sown] on this field. [They also mentioned that] the three fields this field of its seeds and the two fields ........ of their seeds

And that a peasant said: 'Had the sultan set us free to harvest, we would have harvested'. A part of the community celebrated in

Muharram

and the majority [intercalated]. The equinox was in the I2th(?) hour of the night of Monday, I3th Muḥarram. Year 4I7

................. a field was inspected in בהראריא when three nights have passed of Muharram, such that a piece of a field that was riper than the rest was in the green and doughy growth stage and the rest of the grain on the field was less developed than that. The community celebrated in Șafar. This year was intercalated according to the mu'ayyidūn and plain according to the kabbāsūn. ${ }^{23}$ The equinox was in the Ioth hour of the night of Tuesday, 23th of Muharram.

Year 4 I8 On Sunday, the 3oth of Muharram year $4 \mathrm{I} 8$ a field was inspected in the district of Gaza with grain in different [stages].

Three handfuls were taken from its good sides numbering

64 [ears]. They included: milky and curdled -33 , green and doughy -22 , pistachio-coloured -

2I. See n. I8.

22. See 'Locations where fields were inspected' below.

23. On mu'ayyidūn and kabbāsūn, see 'Required amount of aviv barley' below. 
9. From the inferior side three handfuls were taken, numbering 49 [ears]. They included: green and doughy -6 , pistachio-coloured -3 , curdled and milky -40 .

The amount of seeds [sown] was one half and one third of a qafiz. On Monday a field was inspected and three handfuls were taken from the good side, numbering 66 [ears]. They included: pistachio-coloured -26 , dust-coloured and white...- ,

green and doughy -3 , bastard ears ${ }^{24}$ with few kernels... [There were all stages] from dust-coloured and down to what did not show an ear

From the inferior side there were two handfuls numbering 43 [ears]. They included: curdled and milky -26 , green and doughy -7 and with few kernels and bastard ... It is estimated that 6 qafiz of healthy [grain] would result from this half a qafiz of seeds. A peasant mentioned that it will be ripe in Io days and the watchman said until the middle [of the month]. On Tuesday a field was inspected on which there was abundant grain. The majority of it was green and doughy, and the pistachio-coloured was beginning to spread. The community did not agree on the opinion that the festival was in Șafar. The teacher Abū Sa ìd and many in the community intercalated. The equinox was in the hour ...

\section{Calendar chronicles}

RNL Evr Arab I II5I and T-S AS 158.I47 preserve very similar texts. As such they must either represent two copies of the same calendar chronicle or two works of the same genre. It is unclear when and why the chronicles were written. They may have been added to on a yearly basis and represent logbooks kept for practical purposes. It is also possible that the texts were put together some time after the events, perhaps as a scholarly undertaking. This would require keeping barley examination reports past their year of reference. This practice is, indeed, attested in T-S I2.646v and T-S I2.I47, which are copies rather than original barley examination reports, the former from a Qaraite book of court records. It is noteworthy that RNL Evr Arab I II5I and T-S AS I58.I47, which come from different manuscripts, hold data for the same period (4IOS A H). While this could be a coincidence, it can also indicate that the practice of summarizing barley observation reports into chronicles was short-lived and limited to the first half of the eleventh century.

24. The reference here may be to false barley, also known as wall barley. 
That the surviving manuscripts were then copied up to two centuries after the covered years means that Qaraites considered this calendrical information worthy of preservation for posterity.

\section{Structure of an entry}

The following information is provided in RNL Evr Arab I IISI and T-S AS I58.I47 for each year:

I. A heading, which consists of a Hijri date.

2. Observation reports of different parties stating when and where fields were inspected, who performed the observations (not always mentioned), what the growth stage of the crop was, how much grain was sowed and how much yield was expected from each examined field, harvest times as predicted by peasants.

3. Decisions about intercalation made in each year.

4. Date and time of the vernal equinox.

\section{Parties whose observations and}

\section{calendrical decisions are recorded}

In RNL Evr Arab I II5I two persons are mentioned as inspecting fields and making calendrical decisions: the teacher (al-muallim) Abū Sa'ì (4I5 A H, 4I 8 AH) and Abū al-Țayyib Šalom (4I5 A H). These people went to the fields both together and separately (4I5 A H) and at least sometimes made different decisions on the basis of what they observed (4I5 A H). Abū Sa ìd and Abū al-Tayyib Šalom represent the in-group of the compiler of the document, referred to as 'our members' (4I6 A H). Besides, written reports from 'the Qaraites' (4I5 A, $4 \mathrm{I} 6 \mathrm{AH}$ ) and observations of anonymous 'people' (4I6 A H) are taken into account when making calendrical decisions.

T-S AS 158.I47 does not preserve information on who inspected fields but records that a decision was made in 4IO A H by the elder (al-ša $a h$ h $)$ Abū Ya qūb, whose name is accompanied by a blessing for the dead. This decision was different from the decision of the Qaraites. A report of the Qaraites may also be mentioned on the recto. 
In the context of Palestinian Qaraites, al-šayh Abū Yàqūb and al-muiallim Abū Sa ìd may be identified as Abū Yáqūb Yūsuf al-Bașīr and Levi (Abū Sa i id) b. Yefet, who frequently appear in the sources with the appellations al-šayh and al-muallim, respectively. These scholars were associated with the Qaraite academy in Jerusalem in the second half of the tenth-first half of the eleventh centuries and wrote legal works that included sections on the aviv. ${ }^{25}$ However, it is impossible to be certain of these identifications. Both $A b \bar{u}$ Yáqūb and Abū Sa īd are common names. As is explained below, some of Abū Sa'îd's decisions go against Levi b. Yefet's views expressed in his Book of Commandments and the same may be true regarding Abù Yaquūb. ${ }^{26}$ Most importantly, the identification of Abū Yaqūb with Yūsuf al-Bașīr is only possible if the blessing for the dead that accompanies the elder's name in the 4IO A H entry (IOIg/2O CE) was added later since Yūsuf al-Bașīr was still alive as late as the first half of $1037 .{ }^{27}$ The name Abū al-Ṭayib Šalom is, to the best of my knowledge, not recorded in secondary literature and could not be identified in catalogues of Cairo Genizah collections and the Firkovich Collection.

References to 'the Qaraites' are probably to other Qaraite barley observation parties. ${ }^{28}$ That more than one observation party was active at the same time is noted in an aviv report in Oxford, Bodleian Heb. b. II.Io and in a short sixteenth-century guide on seeking the aviv preserved in RNL Evr Arab I II80. The guide states that 'previous generations' used

\footnotetext{
25. Levi b. Yefet, Book of Commandments, 'Discourse on the sign of the year' and 'Discourse on the aviv'; Yùsuf al-Bașīr, Kitāb al-Istibṣār, book 4 .

26. See 'Intercalating two years in a row' and 'The time of inspecting crops and making a decision to intercalate', respectively, below.

27. G. Schwarb, 'Yūsuf al-Bașīr', in Encyclopedia of Jews in the Islamic World; accessed I April 2020.

28. Admittedly, this usage is uncommon. However, it is difficult to imagine that the protagonists of the chronicles were not themselves Qaraite and are juxtaposed here to all Qaraites. By the eleventh century other sects that may have intercalated on the basis of the state of crops, such as the 'Ananites and the followers of Benjamin al-Nahāwendī, became part of the Qaraite movement (M. Gil, 'The Origins of the Karaites', in M. Polliack [ed.], A Guide to Karaite Studies: The History and Literary Sources of Medieval and Modern Karaite Judaism [Leiden: Brill, 2003], pp. 78, 90, II4; H. Ben Shammai, 'Between Ananites and Karaites: Observations on Early Medieval Jewish Sectarianism', Studies in Muslim-Jewish Relations I [1993], pp. 19-29, p. 23). The closest parallel to the use of the term 'the Qaraites' in the sense of 'the other Qaraites' that is known to me is found in fragments of a Qaraite calendar roster associated with the Tustarī clan (ENA 40I0.35, ENA 4I96.I5, T-S K2.IO7r and T-S NS J 6o9r; Gil, The Tustaris, pp. 86-94). While T-S NS J 6o9r contrasts a Tustarī date with that of 'the rest of the Qaraites', in ENA 40I0.35v the comparison is with 'the festival according to the Qaraites and the Rabbanites'. 'The Qaraites' in ENA 4010.35v must mean the same as 'the rest of the Qaraites' in T-S NS J 6ogr. On the Tustarīs' Qaraism, see Rustow, Heresy and the Politics of Community, pp. I4I-2.
} 
to send aviv searching parties from Egypt, Damascus and Jerusalem. ${ }^{29}$ It is likely that expeditions from these three communities performed separate examinations.

Reports of other Qaraites were used by the in-group of RNL Evr Arab I II5I if making a decision to intercalate proved difficult. For example, in 4I5 A H barley crops were sufficiently ripe to celebrate Passover but Abū alTayyib Šalom decided to intercalate. It appears that others tried to convince him against it: Abū Sa îd accompanied him to examine crops in the district of Ascalon and a report of the Qaraites about harvest in Gaza was presented as additional evidence. In $4 \mathrm{I} 6 \mathrm{AH}$ the in-group was unable to go and seek the crops 'for fear of the road' but Qaraites 'sought in the places in which it is habitual to seek' and some people also went to Zoar. Here a decision was made entirely on the basis of this external evidence.

Most barley examination reports, in the chronicles and in other sources, contain information collected from peasants, especially in years when grain in a relatively ripe stage was found. This information is of two kinds: peasants' estimates of the harvesting time and information on the amount of seeds planted and the expected yield. How this information was used and what weight it carried in the decision-making process in comparison with Qaraites' own observations are unclear. The amount of planted seeds and the expected yield may have been important in assessing how representative inspected fields were and whether barley grew and ripened on them in the usual manner, unaffected by special circumstances. It is, perhaps, for the same reason that reports state whether examined fields were good, inferior or damaged.

\section{Aviv barley and other barley growth stages}

The biblical text provides little specific information on what constitutes for barley the state called aviv. This vagueness gave rise to a plethora of opinions regarding the stage or stages in the grain ripening process that should be called aviv and that one should rely upon when making a decision when to celebrate Passover. ${ }^{30}$

29. RNL Evr Arab I iı 80, fol. 8v.

30. Al-Qirqisānī, Book of Lights and Watchtowers, I. I9.2, viı.20.I (Nemoy, Kitāb al-Anwār, vol. I, pp. 6o-6I; vol. 4, pp. 842-3); Levi b. Yefet, Book of Commandments, RNL Evr Arab I 3920, fols 89r-9Ir; Levi b. Yefet, Book of Differences between Yefet b. 'Eli and Sahl b. Mașliah, BL OR 2573, fol. ıor; Yūsuf al-Bașīr, Kitāb al-Istibṣār, book 4, ch. 2, RNL Evr Arab I i I7o, fols 4r-I3rr. 
To understand grain development stages mentioned in literary and documentary sources, it is useful to look at the process of barley ripening as it is described by pre-modern Qaraites. ${ }^{31}$ The guide on seeking the aviv in RNL Evr Arab I II80 lists fifteen stages in the development of barley, noting that it takes grain about three days to move from one stage to the next. ${ }^{32}$ The first four stages precede the emergence of ears and are irrelevant for aviv barley observation since they always occur too early in the year. The following eleven stages are listed for barley that has produced ears (the classification refers to the colour of the ear and/or the state of kernels):

5. heading, pushing out ears (muțliq sunbula)

6. empty (färig)

7. milky (mulabban)

8. curdled (mujabban)

9. green and tender (ahdar ratb)

Io. green and doughy (ahdar dajn or ahdar dājin)

II. pistachio-coloured (fustuqī)

I2. yellow (asfar)

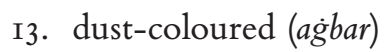

I4. white and tender (abyad raț)

I5. white and dry (abyad yābis)

A note is required here on my translation of mujabban as 'curdled' (stage 8) and ahdar dajn as 'green and doughy' (stage Io). The term mujabban was understood by Gil as 'yellowish green' and ahdar dajn as 'dark green', ${ }^{33}$ the latter presumably derived from the Arabic dajn 'dark, gloomy'. This interpretation of the terms was supported by Blau, who in both cases translated 'a sort of green'. ${ }^{34}$ Corriente translated 'yellowish (i.e. light) and dark green' and conjectured that mujabban in the sense of light green reflects the light green

\footnotetext{
3I. For a modern description of barley growth, see J.C. Zadoks, T.T. Chang and C.F. Konzak, 'A Decimal Code for the Growth Stages of Cereals', Weed Research I4 (1974), pp. 4I5-2I.

32. RNL Evr Arab I iı 80 , fols $4 \mathrm{r}-4 \mathrm{v}$.

33. Gil, A History of Palestine, vol. 2, p. 542 (doc. 30I).

34. J. Blau, Dictionary of Medieval Judaeo-Arabic Texts (Jerusalem: Academy of Hebrew Language, 2006), pp. 80, 205.
} 
colour of some kinds of fermented cheese. ${ }^{35}$ However, the interpretation of mujabban as 'yellowish green' and ahdar dajn as 'dark green' is unlikely in the light of RNL Evr Arab I ir8o, of which Gil, Blau and Corriente were probably not aware. The stage of mujabban appears in the list before 'green and tender' while ahdar dajn comes two stages later, between 'green and tender' and 'pistachio-coloured'. Clearly, the earlier mujabban stage in cereal growth cannot be described as lighter green or yellower than the later ahdar dajn. Since ahdar dajn is placed between 'green and tender' and 'pistachio-coloured', it must refer to a stage when grain is changing colour from greenness to yellowness and cannot be dark green. I suggest that instead of describing colour, dajn is a measure of taste and consistency, and that the pair of stages $a h d a r$ ratb and ahdar dajn is parallel to a later pair of abyad rațb and abyad yābis where the first descriptor refers to the colour of the ear and the second to the state of its kernels. That dajn refers to barley's taste and is separate from its colour is supported by other sources that present theoretical discussions of the aviv. For example:

In terms of taste there is no difference [between qașir and aviv] because aviv has developed full dajn. In terms of colour, aviv is yellow, for which we will bring proof, ${ }^{36}$ and qașir is white. ${ }^{37}$

For these reasons, I prefer to translate dajn as 'doughy', which links with the modern barley ripening stages of early, soft and hard dough, during which the kernel gradually hardens and the ear loses its green colour. ${ }^{38}$ If so, mujabban can also be a descriptor of consistency, when the kernels are 'cheesy' or 'curdled' - that is, more solid than 'milky' but less solid than 'doughy'.

Theoretical works on the aviv pay attention only to the later stages in the crop ripening. The stages of green and doughy, pistachio-coloured, yellow, white and tender, and white and dry are regularly discussed and different opinions are put forth as to which stages are aviv, which are less ripe than aviv and which are more ripe than aviv and represent the harvest stage,

35. F. Corriente, 'Notes on a Basic Work for the Study of Middle Arabic: J. Blau's Millon le-teqstim arbiyim yehudim Miyyeme ha-bbenayim (A Dictionary of Medieval Judaeo-Arabic Texts)', Collectanea Christiana Orientalia 4 (2007), pp. 3II-55, p. 318.

36. This definition of the aviv was supported by some but not by all Qaraites.

37. Intra-Qaraite polemic on the aviv, RNL Evr Arab II 3 IO5, fol. $3 \mathrm{v}$.

38. Zadoks growth scale stages 83-7 (Zadoks et al., 'A Decimal Code', p. 4I8). 
qașir. ${ }^{39}$ In general, one or several stages from among green and doughy, pistachio-coloured and yellow were considered aviv, although many scholars held that green and doughy is below the aviv stage. Admitting that ears on the same field can be in a number of different growth stages, Sahl b. Mașliah (tenth century, Palestine) proposed a quantitative method of determining whether intercalation was required. He suggested taking a handful of barley stalks from the middle of a field and counting ears in each stage. Sahl b. Maṣliah did not intercalate if out of every ten ears six were yellow, two were pistachio-coloured and two were green, and if other fields were in a similar state - that is, if more than half of the grain was yellow. ${ }^{40}$

Actual examination reports mention a wider variety of barley growth stages than are discussed in theoretical works since other stages could also be observed on the fields. Stages between milky and white feature regularly. If grain in multiple developmental stages was discovered on a field, the quantitative method was applied. In RNL Evr Arab I II5I the described practice was to take two or three handfuls of barley stalks from each field or side of a field and either to examine them collectively, counting ears in each developmental stage (4I8 A H), or to examine only the ripest handful (4I6 A H). The results of such counting were open to interpretation and the final decision to intercalate must have depended on each group's definition of the aviv state and on other factors. Surviving fragments of the chronicles do not explicitly mention what barley growth stages were considered ripe enough to celebrate Passover in the thirteenth month, and this may not have been the same for everyone. Only when grain was unripe - that is, green and doughy or below (4I AH, 4I7 AH) - did everyone agree that intercalation was necessary. In all other cases intercalation was possible. Abū al-Ṭayib Šalom intercalated even when all reports showed that fields were harvest-ripe in Muharram 4I5 A H. This suggests that factors other than the growth stage may have played a role in his decision, such as the required amount of aviv barley.

\footnotetext{
39. See references in n. 30 .

40. Sahl b. Mașliah, Book of Commandments, RNL Evr Arab I 823, fol. 26r. See also intra-Qaraite polemic on the aviv, RNL Evr Arab I II63, fol. $46 \mathrm{r}$.
} 


\section{Required amount of aviv barley}

Qaraite legal works lay down various rules on how much grain in the correct stage must be found in order to declare the month of aviv and celebrate Passover. ${ }^{41}$ Some authorities maintained that the mere presence of even the smallest amount of grain in the correct stage was enough. Others were satisfied with a small plot, or a field of a certain size. Many authorities wanted to see aviv widely present in Palestine.

Two terms appear in the sources that characterize people with regard to the amount of aviv barley that they required in order to celebrate Passover in the thirteenth month: mu'ayyidūn ('those who celebrate') and kabbāsūn ('those who intercalate'). ${ }^{42}$ The terms themselves do not refer to required amounts of aviv barley, but their connection with this criterion can be inferred. In an anonymous intra-Qaraite polemic on the aviv, kabbāsūn are described as requiring much aviv grain:

This is a kind of statement that kabbāsün make, to whom you are opposed. And here I can see you reverting to what they say by saying 'a lot [of aviv barley]' and 'a lot' is what they say. ${ }^{43}$

In a similar vein, Oxford, Bodleian Heb. e.45.I7 discusses muiayyidūn and kabbāsün in a section that deals with the amount of aviv barley and contrasts muiayidün with somebody in whose opinion one field in the stage of aviv is not enough to call a month the first month.

Different decisions made by mu'ayyidūn and kabbāsūn are mentioned in RNL Evr Arab I II5I. The entry for 4I7 A H states that the entire community celebrated in Safar and that 'this year was intercalated according to the mu'ayyidün and plain according to the kabbāsūn'. ${ }^{44}$ This means that between Safar 4I7 AH and the beginning of the previous Jewish year there were twelve months according to the kabbāsūn and thirteen months according

4I. Al-Qirqisānī, Book of Lights and Watchtowers, I.I9.2, vir.I9 (Nemoy, Kitāb al-Anwār, vol. I, pp. 60-I, vol. 4, pp. 84I-2); Israel b. Daniel, Book of Commandments, RNL EVR ARAB I IoI2, fols I58v-I59r; Levi b. Yefet, Book of Commandments, RNL Evr Arab I 3920, fols 9Ir-92v; Levi b. Yefet, Book of Differences between Yefet b. 'Eli and Sahl b. Mașliah, BL OR 2573, fol. Ior; Yūsuf al-Bașīr, Kitāb al-Istibșār, book 4, ch. 4, RNL Evr Arab I iI70, fols I5r-22r.

42. Intra-Qaraite polemic on the aviv, RNL Evr Arab I II63, 52r, 53r; Levi b. Yefet, Book of Commandments, RNL Evr Arab I 3920, fols 86r, Iosr; Oxford, Bodleian Heb. e.45.I7.

43. RNL Evr Arab I iı63, fol. 53r.

44. This demonstrates that muiayidūn and kabbāsūn are not simply descriptions of the choices people made each year in a way that those who intercalated in a given year were that year's kabbāsūn. 
to the muiayidūn. Hence, kabbāsūn celebrated previous Passover in Șafar 4I6 A H and mu'ayyidūn in Muharram 4I6 AH. In the entry for 4I6 A H we learn that only 'a part of the community celebrated in Muharram'. These people must have been the mu'ayyidūn. The rest must have intercalated the year and celebrated in Șafar and so must be identical with the kabbāsūn. As can be seen from тавLE 2 in the Appendix, kabbāsūn here are followers of Abū al-Ṭayyib Šalom and some followers of Abū Sa īd who joined them, and mu'ayyidūn are the rest of Abū Sa'ìd's group. That Abū al-Ṭyyib Šalom looked for widespread aviv barley may explain why he intercalated in $4 \mathrm{I} 5 \mathrm{AH}$ when reports showed harvest- or near-harvest-ripe crops on some fields.

\section{Locations where fields were inspected}

Qaraite treatises on the calendar mention a number of regions in Palestine where barley ripens early and where for that reason aviv should be sought. These are the Darom, the district of Ramla, the district of Asqalon, Gaza, the Jordan valley and Zoar. ${ }^{45}$

The chronicles analysed here agree with theoretical treatises and refer to barley inspections in the district of Gaza (4I5 A H and 4I8 AH) and more specifically near Rafah (4IO A H or 4I3 A H), the district of Zoar (4I6 A H), the district of Ramla (4I5 AH) and the district of Ascalon (4I5 A H). I was unable to identify three locations mentioned in the fragments: בשמשה A ) בהראריא (4I7 A H); the region of זגה (4I5 A H). The first two may have been villages in or near which the examined fields were located. From the context, בשמשה appears to have been in the district of Ramla. The third זגר could plausibly be a misreading for either זגה Gaza or Zoar. However, both Gaza and Zoar are identified in the manuscript as 'amal (district, sub-province), whereas זגה is referred to as nāhiya (area). Moreover, understanding זגה as either Gaza or Zoar appears problematic in the context of events in 4I5 A H. The chronicle tells that Abū al-Ṭayib Šalom went to the area of זוגה and came back to Ramla in a year when there was a fear of the

\footnotetext{
45. Levi b. Yefet, Book of Commandments, RNL Evr Arab I 3920, fol. 94v; Levi b. Yefet, Book of Differences between Yefet b. 'Eli and Sahl b. Mașliah, BL OR 2573, fol. Ior; Yūsuf al-Bașīr, Kitāb al-Istibșār, book 4, ch. 5, RNL Evr Arab I i I70, fols 23r-23v.
} 
Bedouins, presumably due to the Bedouin uprising. ${ }^{46}$ It also mentions that a report about the state of crops in Gaza arrived from the Qaraites. If stands for Zoar, an expedition from Ramla to Zoar and back seems unlikely in a year when travel was dangerous. If it indicates Gaza, there would have been no need to consider a report from the Qaraites.

\section{The time of inspecting crops} and making a decision to intercalate

Another aspect of aviv-based intercalation discussed in theoretical works is the time of the thirteenth month when it must be decided whether the year is plain or intercalated. ${ }^{47}$ According to some authors it was essential to know from the beginning or in the first one or two days of the thirteenth month whether it is Nisan or the intercalary month of Adar II. Others were prepared to postpone the decision until seven or ten days of the month have passed. Still others advocated seeking the aviv on the I2th or even the I4th of the thirteenth month.

These different views are reflected in the chronicles. Data in RNL Evr Arab I IIsI show that the Qaraites and Abū al-Ṭayib Šalom did not require that the nature of the thirteenth month be known before the beginning or in the first days of the month. In 4I5 A H and 4I6 A H they inspected crops very close to the middle of the thirteenth month (Muharram in both years). ${ }^{48} \mathrm{It}$ is not clear when Abū Sa îd inspected crops in 4IS A H but it appears that he made a decision before going to Ascalon with Abū al-Ṭayyib Šalom between the Ioth and I3th Muharram. In 4I7 AH and 4I8 A H crops were examined in the beginning of the thirteenth month (Muharram and Șafar respectively) and, although no ripe grain was discovered, they were not re-examined again nearer the middle of the month. In 4I7 A $\mathrm{H}$ even the ripest barley was still green, preventing its becoming sufficiently ripe by the middle of the month. In 4I8 A H barley was riper and peasants assumed that it might

46. See n. I8.

47. Al-Qirqisānī, Book of Lights and Watchtowers, v II .I8 (Nemoy, Kitāb al-Anwār, vol. 4, pp. 839-4I); Levi b. Yefet, Book of Commandments, RNL Evr Arab I 983, fols 223r-223v, RNL Evr Arab I 3920, fols 95v-99r; Levi b. Yefet, Book of Differences between Yefet b. 'Eli and Sahl b. Mașliah, BL OR 2573, fol. Ior; Yūsuf al-Bașīr, Kitāb al-Istibșār, book 4, ch. 6, RNL Evr Arab I I I70, fols 28r-34r.

48. Since both Qaraite and Muslim months begin when the new crescent is sighted, the given days of a Muslim month roughly correspond to the days in a Jewish month. For correspondences between Muslim and Qaraite months as they transpire from the chronicles, see Appendix. 
be harvest-ready by the middle of the month at the latest. Nonetheless, a large part of the community, led by Abū Sa ${ }^{i} \mathrm{~d}$, decided to intercalate. This suggests that $A b \bar{u}$ Saìd required that the nature of the thirteenth month be established already in the beginning of the month, a position that strengthens his identification with Levi b. Yefet, who was in favour of checking the aviv in the beginning of the month. ${ }^{49}$

In T-S AS I58.I47 not enough information on the time of seeking aviv barley is preserved. The beginning of a month is mentioned in the entry for 4IO А н (but the context is lost), and observing a field when three nights have passed of a month is recorded on recto. This may suggest that the fragment's in-group required the state of barley crops to be assessed around the beginning of the month (unless observations were also performed nearer the middle of the month but no mention of them survived). If this is correct, it may weaken the identification of Abū Yaqūb with Yūsuf al-Bașīr, who originally advocated examining barley up to the I4th day of the month but later changed his opinion in favour of the beginning of the month. ${ }^{50}$

\section{Intercalating two years in a row}

A distinctive feature of Qaraite calendars reflected in the chronicles is that two years in a row can be intercalated. In 4IS A H Abū al-Ṭayyib Šalom intercalated the year after intercalating the one before it. In 4I8 A H Abū Sa ${ }^{i} \mathrm{~d}$ and many in the community intercalated, whereas $4 \mathrm{I} 7 \mathrm{AH}$ was intercalated for all. This situation is precluded in the Rabbanite calendar where intercalated years are always two or three years apart. In Qaraite calendar literature conflicting views of consecutive intercalated years are attested. In the intra-Qaraite polemic on the aviv one polemicist defended his definition of the aviv on the basis that it ensured that no two years in a row were intercalated and no year was just eleven months long, whereas the other polemicist claimed that two intercalated years were allowed. ${ }^{51}$ Levi b. Yefet opined that intercalating two years one after the other deviated from the natural order of years and explained that he neither witnessed it nor

\footnotetext{
49. Levi b. Yefet, Book of Commandments, RNL Evr Arab I 3920, fol. $96 v$.

50. Yūsuf al-Bașīr, Kitāb al-Istibșār, book 4, ch. 6, RNL Evr Arab I II7o, fols 3Iv-32r. Abū al-Faraj Hārūn, Talhịis, RNL Evr Arab I 1754, fol. I68v.

5I. RNL Evr Arab II 3 I05, fol. I3v; RNL Evr Arab I iा63, fol. I6v.
} 
heard of it happening. ${ }^{52}$ This weakens the identification of Abū Sa î̀ with Levi b. Yefet.

\section{The equinox}

In each year RNL Evr Arab I II5I and T-S AS I58.I47 provide data on the vernal equinox $\left(i t^{i} i \bar{a} l\right) .{ }^{53}$ It is not clear whether and how this data was used. Levi b. Yefet wrote that intercalation based on the vernal equinox was a method used by Qaraites in Iraq. ${ }^{54}$ The equinox method was rejected by such Palestinian Qaraites as Yūsuf al-Bașīir ${ }^{55}$ and Sahl b. Mașliaḥ. ${ }^{56}$ Levi b. Yefet himself had a more nuanced attitude. While arguing against it as the main method of intercalation, he considered the vernal equinox to be a good substitute for the aviv in years when irregular weather patterns led to a much earlier- or a much later-than-expected ripening of barley crops. ${ }^{57}$

\section{Calendar diversity}

In this section I analyse the extent of calendar diversity among Qaraites and between Qaraites and Rabbanites in the years covered by the chronicles. Data on the Rabbanite intercalation is not given in the manuscripts but can be deduced from the position of the years in the nineteen-year cycle. The section deals only with discrepancies of a whole month, which follow from different approaches to intercalation. Qaraites and Rabbanites regularly celebrated roš hodeš on different days of the week because the calculated roš hodes of the Rabbanites generally falls before the new crescent can be observed. Such discrepancies of a few days at the beginning of most months are outside of the chronicles' area of interest and are not discussed here. Inasmuch as it is not entirely clear that T-S AS I58.I47 and RNL Evr Arab I II5I are copies of the same work and describe the same groups of Qaraites, I treat them separately so far as calendar diversity is concerned.

52. Levi b. Yefet, Book of Commandments, RNL Evr Arab I 3920, fols Io5r-Io5v.

53. The given dates and times of the equinoxes do not correspond to the Rabbanite tequfot.

54. Levi b. Yefet, Book of Commandments, RNL Evr Arab I 3920, fol. 82r.

55. N. Vidro, 'The Book against the People of the Equinox: T-S K6.63', Fragment of the Month: September 2019, Taylor-Schechter Genizah Research Unit, Cambridge; https://doi.org/Io.I7863/ CAM.63288 (accessed 2 April 2020).

56. Sahl b. Mașliah, Book of Commandments, RNL Evr Arab I 823, fol. 27v.

57. Levi b. Yefet, Book of Commandments, RNL Evr Arab I 3920, fols 87r-87v. 
T-S AS I58.I47 records the following calendar decisions of Abū Yaquīb and of other Qaraites:

4Iо Aн: The Qaraites intercalated and Abū Yáqūb celebrated.
4II Aн: The community celebrated, without any doubts, in Dū al-Hijjah.
Since no other parties are mentioned in the fragment, I assume that
'the community' here included the followers of Abū Ya'qūb and the
Qaraites.

RNL Evr Arab I iısI records calendar decisions of Abū Sa īid, Abū al-Ṭayyib Šalom and, in some years, of parts of the community that are not described as following any particular leader:

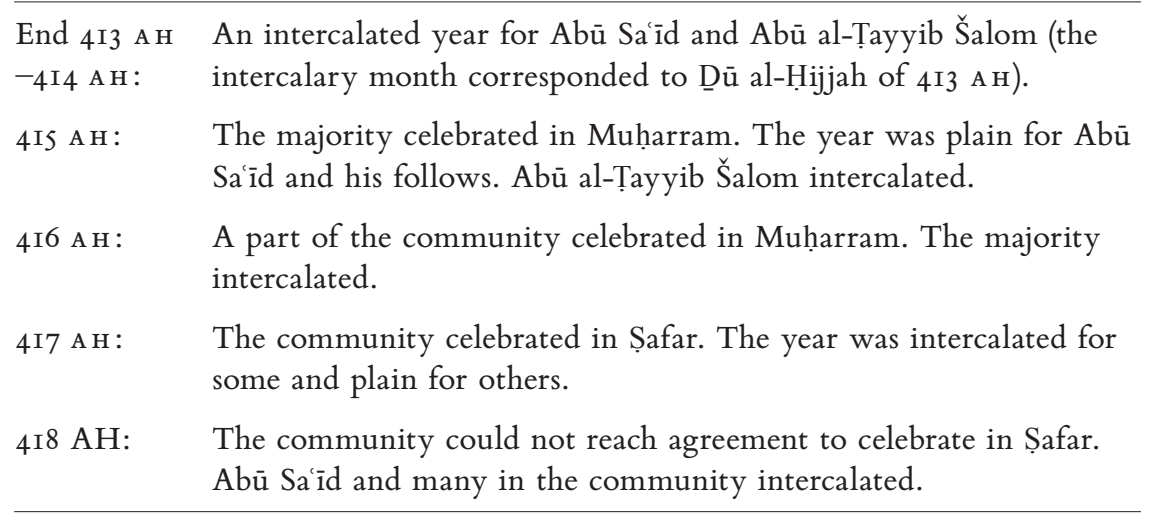

Correspondences between the Muslim calendar, the Qaraite calendars in the chronicles and the Rabbanite calendar for end 409-4I8 A H are established in tABLES I and 2 in the Appendix. Summary tables below focus on the Jewish calendars and in particular on the months of Tišri and Nisan, when most important Jewish festivals take place. In some years data is available for only one of these months. The tables allow the visualization of the extent of intra-Qaraite and Qaraite-Rabbanite calendar diversity. For convenience, dates from the Era or Creation are used in the summary tables, with Hijri dates given in brackets.

The following picture emerges. Calendar diversity among Qaraites and between Qaraites and Rabbanites was very common in 4779-88 A M. Passover was celebrated in two different months in four out of nine years for which 
4779-82 А м $(409-12$ А H $)$

\begin{tabular}{llll}
\hline & $A b \bar{u}$ Yàqūb & Other Qaraites & Rabbanites \\
\hline $4779(409)$ & Nisan & Nisan & Nisan \\
$4780(4$ IO) & Tišri & Tišri & Tišri \\
& Nisan & Adar II & Adar II \\
478 I (4II) & Marḥešwan & Tišri & Tišri \\
& Nisan & Nisan & Nisan \\
$4782(4$ I2) & Tišri & Tišri & Tišri \\
\hline
\end{tabular}

information can be derived from the chronicles, and so was New Year. If one considers only those years for which information is available both for Tišri and for Nisan (4780-8I A M and 4783-87 A M), only in 4783 A M did all groups celebrate all festivals in the same month. On the other hand, the calendars never drifted apart for long. In five years out of nine, the calendar for the period between Nisan and the following Tišri was identical for all groups.

$4782-87$ А $M(412-18$ A H $)$

\begin{tabular}{llll}
\hline & Abū Sa ${ }^{i} \bar{i} d$ & Abū al-Tayyib Šalom & Rabbanites \\
\hline $4782(4 \mathrm{I} 2)$ & Nisan & Nisan & Nisan \\
$4783(4 \mathrm{I} 3)$ & Tišri & Tišri & Tišri \\
$(4 \mathrm{I} 4)$ & Nisan & Nisan & Nisan \\
4784 & Tišri & Tišri & Tišri \\
$(4 \mathrm{I} 5)$ & Nisan & Adar II & Nisan \\
4785 & Tišri & Elul & Tišri \\
$(4 \mathrm{I} 6)$ & Nisan $\quad$ Adar II & Adar & Nisan \\
4786 & Tišri $\quad$ Elul & Elul & Tišri \\
$(4 \mathrm{I} 7)$ & Nisan & Nisan & Nisan \\
4787 & Tišri & Tišri & Tišri \\
$(4 \mathrm{I} 8)$ & Adar II & Nisan & Nisan \\
4788 & Elul & Tišri & Tišri \\
\hline
\end{tabular}

58. This assumes that the same group of Qaraites followed Abū Sa íd in the spring of 4787 A M (4I8 $\mathrm{AH}$ ) as in the spring of $4784 \mathrm{~A} \mathrm{M}(4 \mathrm{IS} \mathrm{A} \mathrm{H})$. It is also possible that Abū Sa ìd's group was split again as they were in $4785 \mathrm{~A} \mathrm{M}(4 \mathrm{I} 6 \mathrm{~A} \mathrm{H})$, and a part of the group joined another party and celebrated Passover. 
Cases of calendar diversity between Qaraites and Rabbanites and among the Qaraites themselves are known from other sources. ${ }^{59}$ A new insight afforded by the chronicles edited here is that intra-Qaraite calendar diversity was much more common than discrepancies between Qaraites and Rabbanites, at least in Ior9-28 C E. Indeed, in all years with a calendar difference the split was not between Rabbanites and all Qaraites, but within the Qaraite community. Considering the many different methods of fixing the calendar on the basis of the aviv described in theoretical works, this intra-Qaraite diversity is not unexpected but its extent in practice has not previously been described. Apart from the frequency of the divides, the fluidity of intra-Qaraite calendar groups is noteworthy. Such groups were not fixed but could split and realign. The party that followed Abū Sa î̀ in 4784 A M (4I5 A H) split in 4785 A M (4I6 A H), some of them accepting the decision of Abū al-Ṭayib Šalom. Another regrouping may have taken place in 4787 A м (4I8 Ан) when some Qaraites followed Abū Saîd, but it is not clear that they were the same people who originally followed him in $4784 \mathrm{Am}$ (4I5 A H $){ }^{60}$

It was previously assumed that decisions regarding aviv-based intercalation were made by a central authority, either the nesi'im or the Qaraite academy, and distributed to Qaraite congregations. ${ }^{61}$ This scholarly assumption reflects the Rabbanite idea that everyone should follow the same calendar. The chronicles demonstrate that at least in the first half of the eleventh century Qaraites did not follow centrally made decisions about intercalation. Instead, decisions could be made independently by those groups that had access to barley fields in Palestine. If my conjectural identification of the chronicles'

\footnotetext{
59. A I063 C E Qaraite betrothal deed refers to a one-month 'discrepancy between the [Rabbanite and Karaite] communities' in Fusțāṭ (T-S 20.42; J. Olszowy-Schlanger, Karaite Marriage Documents from the Cairo Geniza: Legal Tradition and Community Life in Mediaeval Egypt and Palestine [Leiden: Brill, I998], pp. 298-300 [doc. 6]). A conflict over a similar discrepancy occurred in Byzantium in the eleventh century (T-S 20.45; Ankori, Karaites in Byzantium, pp. 328-36). A Qaraite betrothal formulary that mentions $1009 \mathrm{CE}$ includes a dating formula in the event of a month's difference between the calendars of the bride and the groom (RNL Evr II A 506, fol. Ir; Olszowy-Schlanger, Karaite Marriage Documents, p. 463 [doc. 55]). A draft Qaraite betrothal deed is dated $\mathrm{IO}_{32} / 3$ CE in a month 'which is Av for the majority of the Qaraites, and which is Elul for some of them' (T-S J 3.47v; Olszowy-Schlanger, Karaite Marriage Documents, pp. 300-2 [doc. 7]).

6o. See n. 58.

61. E. Bareket, 'Karaite Communities in the Middle East during the Tenth to Fifteenth Centuries', in M. Polliack (ed.), A Guide to Karaite Studies: The History and Literary Sources of Medieval and Modern Karaite Judaism (Leiden: Brill, 2003), pp. 237-52, p. 242; Gil, A History of Palestine, vol. I, sec. 929.
} 
protagonists is correct, some of the decision-makers were scholars associated with the Qaraite academy in Jerusalem.

The chronicles' data on calendar diversity among Qaraites makes it necessary to reconsider M. Gil's views on the calendar of the Tustarīs. A calendar roster from the Cairo Genizah records that the Tustari calendar was a month ahead of that followed by the rest of the Qaraites in I047/8 CE and IO49-5I CE. ${ }^{62}$ This led Gil to believe that their calendar was fundamentally different and possibly based on calculation. ${ }^{63}$ Gil also assumed that the Tustarīs were unique in following a different calendar from the rest of the Qaraites and ascribed all cases of intra-Qaraite calendar diversity to the use of the Tustarī calendar. ${ }^{64}$ This now seems unlikely. First, Qaraite theoretical works refer to Tustari opinions on the aviv, a clear sign that their calendar was not calculated. ${ }^{65}$ Second, the chronicles discussed here prove that calendar diversity existed among Qaraites who relied on the aviv. It is now clear that the Tustarīs were not unique in sometimes deviating from other Qaraite groups in matters of calendar.

\section{Conclusions}

In this article I have examined two Qaraite calendar chronicles that document barley observations and decisions regarding intercalation made on their basis in IOI9-28 CE. The chronicles provide evidence of the practical implementation of divergent opinions about intercalation and aviv in Qaraite theoretical works. The chronicles demonstrate that a number of barley observation parties were active simultaneously examining fields in different regions. The parties exchanged information, which could then be taken into consideration when making calendrical decisions. Multiple factors influenced a party's decision to intercalate, including barley growth stage, the amount of discovered aviv barley and, possibly, harvesting times predicted by

62. ENA 40I0.35, ENA 4I96.I5, T-S K2.I07r and T-S NS J 6o9r; Gil, The Tustaris, pp. 86-94.

63. Gil, The Tustaris, p. 63 .

64. See Gil's analysis of T-S J 3.47v, dated to a month 'which is Av for the majority of the Qaraites, and which is Elul for some of them', where he identified the minority as the Tustaris on the basis of the calendar difference alone (Gil, A History of Palestine, vol. I, sec. 929; Gil, The Tustaris, pp. 62-3). Rustow, Heresy and the Politics of Community, p. I42, notes that there is no evidence for this identification.

65. RNL Evr Arab I ir64v. 
local peasants. The chronicles demonstrate that while everyone agreed that it was important to intercalate on the basis of the state of barley crops, in practice as well as in theory there was little agreement on how to determine this status.

It is now clear that at least in the first half of the eleventh century Qaraite decisions about intercalation were not sent out by a central authority but could be made independently by groups with access to barley fields in Palestine. It is possible that members of the Qaraite academy in Jerusalem were involved in the process of intercalation; nothing in the chronicles hints at the involvement of nesi'im.

Together with other sources, the chronicles attest to frequent calendar difference among Qaraites and between Qaraites and Rabbanites in eleventh-century Palestine and Egypt. Between IOI9 and IO28 CE various Qaraite groups differed among themselves more often than they differed from the Rabbanites. A notable feature of this intra-Qaraite calendar diversity was that factions did not stay fixed but could split and realign, without any perceptible social consequences. All evidence currently known to me of calendar diversity among aviv-observing Qaraites is for the first half of the eleventh century. It remains to be investigated if this is historically significant or merely a reflection of what happens to survive. On the whole, the chronicles make it clear that the Qaraite calendar of the period was not a monolithic calendar counterposed to that of the Rabbanites and that it is unjustified to speak of a clear calendar divide along denominational lines other than in matters of theory, on the question of whether intercalation should be empirical or based on a fixed calculated scheme. 
APPENDIX Calendar correspondences between the Muslim calendar, Qaraite calendars in the chronicles and the Rabbanite calendar in 409-I9 AH

TABLES I and 2 establish correspondences between Muslim, Qaraite and Rabbanite months as they follow from T-S AS I58.I47 and RNL Evr Arab I II5I respectively. TABLE I covers end 409-4I2 AH, TABLE 2 covers end $4 \mathrm{I} 2$-beginning 4I9 A H. Inasmuch as it is uncertain that the two manuscripts are copies of the same chronicle, the tables are not combined into one. Correspondences between the Muslim and the Rabbanite calendar follow Fourmilab's calendar converter www.fourmilab.ch/documents/calendar. Both tables were extended beyond the dates covered by the chronicles due to the fact that no variation of a full month is possible in the Jewish calendar between Adar and the previous Nisan.

TABLE I T-S AS I58.I47

\begin{tabular}{|c|c|c|c|c|}
\hline & Muslim & $A b \bar{u} Y a^{\prime} q \bar{u} b$ & Other Qaraites & Rabbanites \\
\hline \multirow[t]{2}{*}{$409 \mathrm{AH}$} & Dū al-Qa'dah & Nisan & Nisan & Nisan \\
\hline & Dū al-Hijjah & Iyyar & Iyyar & Iyyar \\
\hline \multirow[t]{4}{*}{ 4IO A H } & Muḥarram & Siwan & Siwan & Siwan \\
\hline & Șafar & Tammuz & Tammuz & Tammuz \\
\hline & Rabī' I & $\mathrm{Av}$ & $\mathrm{Av}$ & $\mathrm{Av}$ \\
\hline & Rabī' II & Elul & Elul & Elul \\
\hline \multirow[t]{8}{*}{4780 А $\mathrm{M}$} & Jumādā I & Tišri & Tišri & Tišri \\
\hline & Jumādā II & Marḥešwan & Marḥešwan & Marḥešwan \\
\hline & Rajab & Kislew & Kislew & Kislew \\
\hline & Ša bān & TTevet & TTevet & TTevet \\
\hline & Ramaḍān & Ševaț & Ševaț & Ševaț \\
\hline & Šawwāl & Adar & Adar & Adar \\
\hline & Dū al-Qa'dah & Nisan & Adar II & Adar II \\
\hline & Dū al-Hijjjah & Iyyar & Nisan & Nisan \\
\hline \multirow[t]{4}{*}{4 II AH } & Muharram & Siwan & Iyyar & Iyyar \\
\hline & Șafar & Tammuz & Siwan & Siwan \\
\hline & Rabīi I & $\mathrm{Av}$ & Tammuz & Tammuz \\
\hline & Rabīi II & Elul & $\mathrm{Av}$ & $\mathrm{Av}$ \\
\hline
\end{tabular}


3 IO JOURNAL OF JEWISH STUDIES

\begin{tabular}{|c|c|c|c|c|}
\hline & Jumādā I & Tišri & Elul & Elul \\
\hline \multirow[t]{7}{*}{ 478I А M } & Jumādā II & Marḥešwan & Tišri & Tišri \\
\hline & Rajab & Kislew & Marḥešwan & Marḥešwan \\
\hline & Ša bān & Țevet & Kislew & Kislew \\
\hline & Ramaḍān & Ševaț & Ṭevet & Ṭevet \\
\hline & Šawwāl & Adar & Ševaț & Ševaț \\
\hline & Dū al-Qa'dah & Adar II & Adar & Adar \\
\hline & Dū al-Hijjah & Nisan & Nisan & Nisan \\
\hline \multirow[t]{5}{*}{$4 \mathrm{I} 2 \mathrm{AH}$} & Muḥarram & Iyyar & Iyyar & Iyyar \\
\hline & Șafar & Siwan & Siwan & Siwan \\
\hline & Rabī' I & Tammuz & Tammuz & Tammuz \\
\hline & Rabī' II & $\mathrm{Av}$ & $\mathrm{Av}$ & $\mathrm{Av}$ \\
\hline & Jumādā I & Elul & Elul & Elul \\
\hline \multirow[t]{6}{*}{4782 А M } & Jumādā II & Tišri & Tišri & Tišri \\
\hline & Rajab & Marḥešwan & Marḥešwan & Marḥešwan \\
\hline & Ša bān & Kislew & Kislew & Kislew \\
\hline & Ramaḍān & Ṭevet & Ṭevet & Ṭevet \\
\hline & Šawwāl & Ševaț & Ševaț & Ševaṭ \\
\hline & Dū al-Qa'dah & Adar & Adar & Adar \\
\hline
\end{tabular}

тAвle 2 RNL Evr Arab I iIsI

\begin{tabular}{|c|c|c|c|c|}
\hline & Muslim & $A b \bar{u} S_{a} \bar{i} d$ & $\begin{array}{l}\text { Abū al-Tayyib } \\
\text { Šalom }\end{array}$ & Rabbanites \\
\hline $4 \mathrm{I} 2 \mathrm{AH}$ & Dū al-Hijjah & Nisan & Nisan & Nisan \\
\hline \multirow[t]{5}{*}{$4 \mathrm{I} 3 \mathrm{~A} \mathrm{H}$} & Muhararram & Iyyar & Iyyar & Iyyar \\
\hline & Șafar & Siwan & Siwan & Siwan \\
\hline & Rabī' I & Tammuz & Tammuz & Tammuz \\
\hline & Rabī' II & $\mathrm{Av}$ & $\mathrm{Av}$ & $\mathrm{Av}$ \\
\hline & Jumādā II & Elul & Elul & Elul \\
\hline \multirow[t]{4}{*}{4783 А $\mathrm{M}$} & Jumādā II & Tišri & Tišri & Tišri \\
\hline & Rajab & Marḥešwan & Marḥešwan & Marḥešwan \\
\hline & Ša bān & Kislew & Kislew & Kislew \\
\hline & Ramaḍān & Țevet & Țevet & Țevet \\
\hline
\end{tabular}


AVIV BARLEY AND CALENDAR DIVERSITY $\mid 3$ II

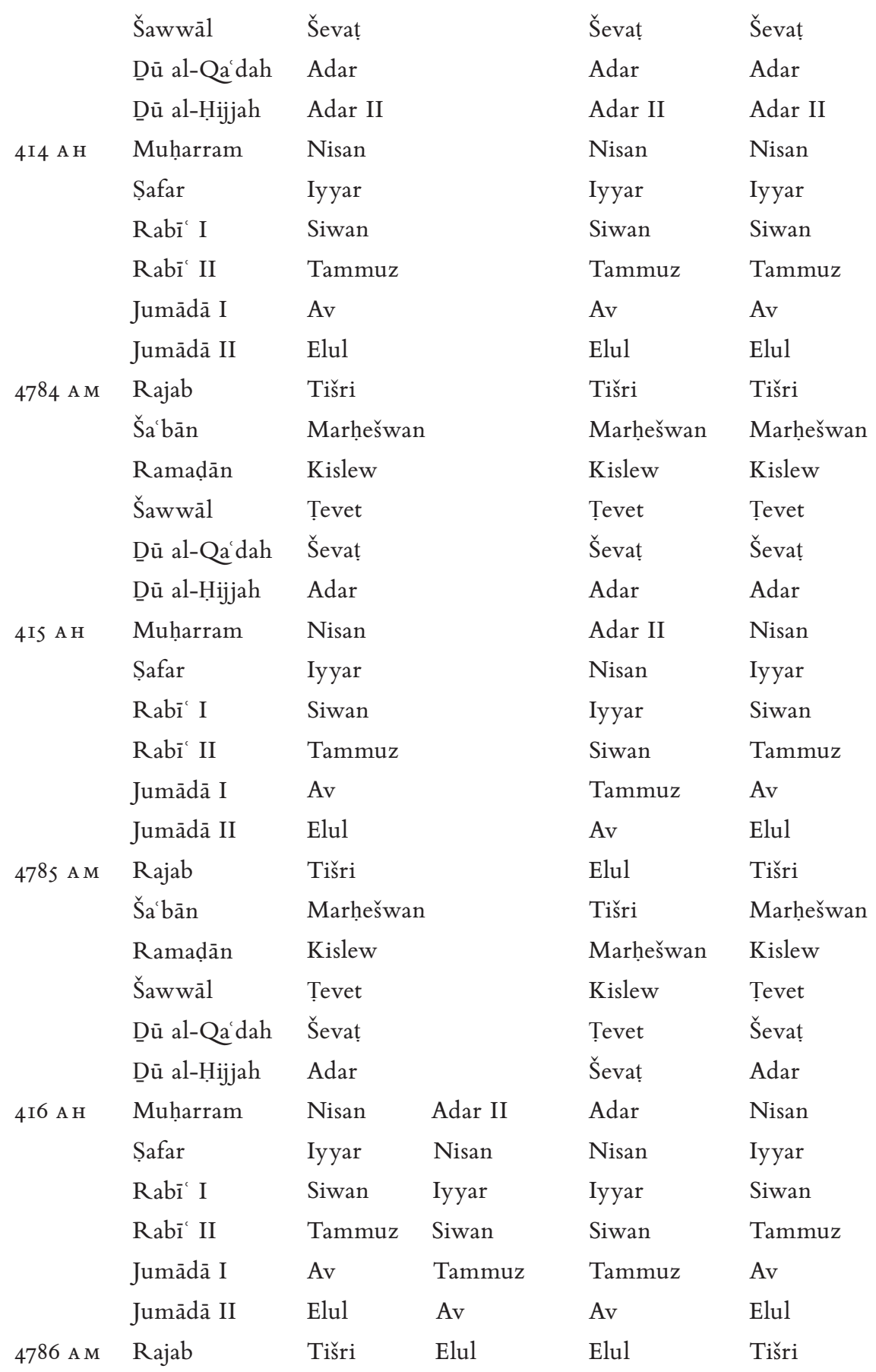


3 I 2 JOURNAL OF JEWISH STUDIES

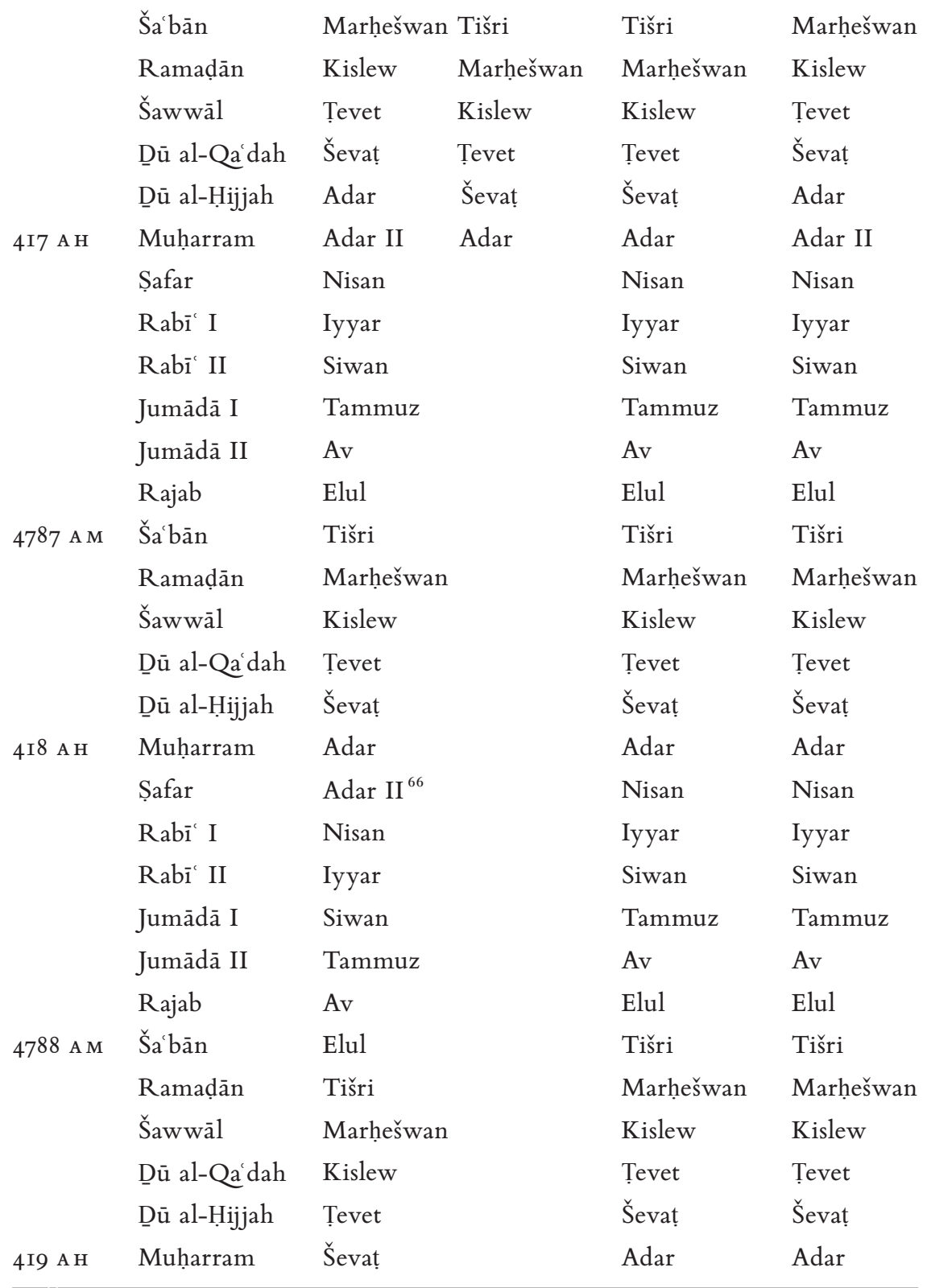

66. See n. 58 